\title{
Chrystocentryczna interpretacja ludzkiego życia w przepowiadaniu
}

Zadaniem Kościoła jest pomóc człowiekowi w odkryciu sensu życia w Jezusie Chrystusie. Misję tę wypełnia on w szczególny sposób w przestrzeni przepowiadania słowa Bożego, dając w niej chrześcijańską interpretację ludzkiego życia. Jej podstawą jest Ewangelia, życie i nauczanie Jezusa Chrystusa, Jego tajemnica, Jego swoista mądrość życiowa, wiedza o życiu. Dlatego interpretacja ta - podobnie jak cała kościelna posługa słowa - ma zawsze charakter chrystocentryczny.

\section{Człowiek potrzebuje wiedzy o życiu}

Człowiek, ażeby móc sensownie układać i interpretować swoje życie, potrzebuje wiedzy o życiu, wiedzy życiowej ${ }^{1}$. Jednakże wiedzy tej my, ludzie, nie czerpiemy z siebie samych. Zazwyczaj przekazywana

1 Zob. P. M. Zulehner, Helft den Menschen leben. Für ein neues Klima in der Pastoral, Freiburg i. Br. 1978, s. 12-24. 
jest nam przez innych. Dlatego odnajdywany przez nas sens życia jest konstrukcją wypracowaną, niesioną i przekazywaną nam przez wspólnotę, w której żyjemy, np. społeczeństwo. Dzisiejsze pluralistyczne społeczeństwo - w porównaniu z należącym już do przeszłości społeczeństwem chrześcijańskim - daje człowiekowi, co prawda, dużo więcej możliwości życiowych, ale jednocześnie wcale nie przydaje więcej sensu jego życiu, o czym świadczy rosnąca liczba tych, którzy tego sensu w ogóle już nie widzą. Żeby ten sens dostrzec, aby żyć sensownie i mieć poczucie spełnienia, ludzie potrzebują „orientacji i interpretacji” ${ }^{2}$. Człowiek jest człowiekiem właśnie przez to, że nie jest „zaprogramowany”, że może coś „zrobić” ze swoim życiem. Życie ludzkie nabiera sensu, kiedy człowiek swoje życie świadomie planuje, projektuje, podchodzi doń kreatywnie, czyli je tworzy. Do tego jednak potrzebuje on dostępu do wiedzy o życiu, rozumianej jako sumy istotnych dla życia „mądrości”, „prawd”, które mu pomagają żyć w poczuciu sensu i wypełnić sensem całe swoje życie.

Sięgając do tradycji ludzkiej myśli, można wyróżnić trzy zasadnicze wymiary tej „wiedzy o życiu”, która, notabene, jest bardzo blisko spokrewniona z biblijną, starotestamentową "mądrością" ${ }^{3}$ : pierwszy to: miłość, eros, agape, seksualność; drugi: autorytet, władza, wolność; trzeci zaś to: własność, możność, dokonania. Niektórzy mówią po prostu: płeć, ambicja i pieniądz. Natomiast nowoczesna psychologia mówi o trzech zasadniczych ludzkich dążeniach: o dążeniu do miłości, dążeniu do uznania i dążeniu do posiadania. A według wielkiego rosyjskiego pisarza Fiodora Dostojewskiego to trzy postawy człowieka: pożądanie, pycha i chciwość decydują o kształcie ludzkiego życia ${ }^{4}$.

2 Tamże, s. 12.

3 Zob. P. M. Zulehner, Leibhaftig glauben. Lebenskultur nach dem Evangelium, Freiburg i. Br. 1983, s. 15-30.

4 Taką wymowę ma przede wszystkim jedno najwybitniejszych jego dzieł, powieść Bracia Karamazow (1880). 
Poszukując sensu życia, człowiek musi znaleźć mądrą odpowiedź na pytanie, jak podchodzić do tych rzeczywistości, jak je wykorzystywać i, co najważniejsze, jak je w swoim życiu kreatywnie rozwijać. A na jakie odpowiedzi, na jaką „wiedzę o życiu” może liczyć dziś człowiek w społeczeństwie pluralistycznym? Paul M. Zulehner odpowiada na to pytanie za pomocą obrazu:

Społeczeństwo podsuwa dziś ludziom mnóstwo różnych krzeseł. Większość „siedzi” dość wygodnie, nawet jeśli co jakiś czas, na pewien czas, zmieniają krzesła. Niektórym jednak nie udaje się zająć miejsca na żadnym z oferowanych krzeseł, inni zaś siadają między nimi. Ten i ów stale potrzebuje kogoś, kto - niczym bileter w teatrze - wskaże mu właściwe miejsce. Są też i tacy, którzy chcą jednej szerokiej ławy dla wszystkich. ${ }^{5}$

\section{Jezusowa wiedza o życiu}

Kościól, jego wspólnoty i pojedynczy wierzący również i w naszych czasach głoszą, że pewna, niezawodna droga do pełni życia, do życia w obfitości, została otwarta w Jezusie Chrystusie, który sam o sobie mówi: „Ja jestem drogą i prawdą, i życiem” $(J 14,6)$. Kościół od wieków niesie i przekazuje ludziom „Jezusową wiedzę o życiu”6. W jaki sposób Jezus interpretował i wiódł swoje życie?

Centralną rzeczywistością życia Jezusa jest Bóg. Jego „wiedza życiowa” i „droga życiowa” opiera się na Bogu, którego nazywa On

5 P. M. Zulehner, Helft den Menschen leben, dz. cyt., s. 23n, tłum. A. Kalbarczyk; zob. tenże, Pastoraltheologie. Fundamentalpastoral, Düsseldorf 1989, s. 197-200.

6 Pojęcie to stworzył wiedeński pastoralista, Paul M. Zulehner (niem. Lebenswissen Jesu); zob. P. M. Zulehner, Helft den Menschen Leben, dz. cyt., s. 25-43; por. A. Friedrich, Geistliches Wort und moderne Gesellschaft. Zu religiöser Literatur heute , Erbe und Auftrag" 2 (2006), s. 187n. 
swoim Ojcem, $A b b a$ (np. Mt 26, 39: „Ojcze mój, jeśli to możliwe, niech ominie mnie ten kielich”). On jest dla Niego „skałą” (np. Ps 94, 22), „tarczą” (np. Ps 18, 31), „schronieniem” (np. 2 Sm 22, 3), ostatecznym życiowym odniesieniem. Do Niego zwraca się podczas swoich długich nocnych modlitw w samotności, ku Niemu zmierza drogą krzyżową, Jemu w chwili cierpienia i śmierci oddaje się całkowicie, „na przepadłe" 7 .

Jednakże głównym motywem Jego życiowej orientacji i interpretacji życia jest prawda o tym, że Bóg szuka człowieka, zanim jeszcze człowiek zacznie szukać Boga; że Bóg wychodzi człowiekowi naprzeciw, zanim jeszcze człowiek wyruszy w drogę ku Niemu. Prawda ta stanowi absolutne novum w przekazywanej przez Jezusa „mądrości życiowej”. Jest to prawda unikatowa, typowa, właściwa tylko Jego stylowi życia i nauczaniu, stanowiąca serce Jego Ewangelii życia. To, że możemy iść ku Bogu, że w ogóle możemy żyć i poruszać się (por. Dz 17, 28), zawdzięczmy właśnie Temu, który wychodzi nam naprzeciw - Bogu żywemu, Dawcy życia. Odnajdywanie sensu życia i prawdziwe życie człowieka nie rozpoczyna się zatem od jego zwrotu ku transcendencji, lecz ma swój początek w descendencji, w zstąpieniu, wyjściu ku człowiekowi Boga miłującego i miłosiernego, który ma w nim „upodobanie”. Bóg Jezusa Chrystusa nie wyrasta więc z ludzkiej potrzeby religijnej. Jest to Bóg, który przychodzi do człowieka, jeszcze zanim ta potrzeba w ogóle się w nim pojawi.

Jezus ukazuje nam bardzo plastyczny obraz Boga, swojego Ojca. Jest to Bóg, który nie jawi się człowiekowi wyłącznie jako mysterium fascinans i mysterium tremens ${ }^{8}$, lecz zbliża się do niego tu i teraz. Jest

7 Wyrażenie pochodzi ze zdania wypowiedzianego przez bł. Sancję Szymkowiak, serafitkę, uznawanego za jej duchowy testament: "Jak się oddać Bogu, to oddać się na przepadłe". Zob. R. Forycki, Wierna "Przymierzu z odwieczna Mąrościq", w: Sylwetka duchowa błogosławionej S. Sancji Janiny Szymkowiak, Kraków 2003, s. 156.

8 Zob. R. Otto, Świętość. Elementy irracjonalne w pojęciu bóstwa a ich stosunek do elementów racjonalnych, tłum. Bogdan Kupis, Warszawa 1968, s. 41n. 
to Bóg całkowicie zainteresowany, zafascynowany człowiekiem, otwarty, na przymierze, na relację z nim. Sam Jezus jest obliczem, które Bóg zwrócił ku człowiekowi i które ukazuje nam, jaki Bóg jest naprawdę. Wszystko to zawiera w sobie przesłanie, że Bóg ma wobec człowieka plan. Czyni go „nowym stworzeniem” (zob. 2 Kor 5, 17), "nowym człowiekiem” (zob. Ef 4, 24), chce dać mu "nowe serce” (zob. Ez 36, 26), chce go nawrócić ku sobie, przemienić, ażeby odkrył w Nim swoje nowe życiowe szanse i możliwości, a przede wszystkim źródło życiowego spełnienia.

"Stary człowiek” (zob. Ef 4, 22) odczuwa w sobie głębokie rozdarcie. $Z$ całego serca pragnie życia w pokoju, radości i miłości, ale cierpi jednocześnie z powodu swoich win, samotności, nietrwałych relacji z drugim człowiekiem, z Bogiem, czy wręcz niezdolności do ich nawiązywania. Dlatego może powtórzyć za św. Pawłem: „Nieszczęsny ja człowiek! Któż mnie wyzwoli z ciała, [co wiedzie ku] tej śmierci?" (Rz 7, 24).

Wyzwolicielem z tej śmierci jest Jezus Chrystus. Dlatego Paweł dodaje: „Dzięki niech będą Bogu przez Jezusa Chrystusa, Pana naszego!” (Rz 7, 24). To On, Jego nowy sposób życia i jego nowa interpretacja życia stanowią alternatywę do „starego człowieka”, „starego sposobu życia”, do - jak pisze św. Paweł - „poprzedniego sposobu postępowania” (Ef 4, 22) i starego „myślenia” (Ef 4, 23). To, że Jezus całe swoje życie odnosi do miłującego Go Ojca, rodzi istotne konsekwencje dla Jego sposobu życia i zapatrywania na życie: jeżeli Bóg jest Ojcem wszystkich, to wszyscy są dla siebie wzajemnie braćmi i siostrami. A to znaczy też, że miłujący nas Bóg, nie chce mieć nas tylko dla siebie, nie chce, żebyśmy żyli tylko dla Niego, ale żebyśmy my, ludzie, mieli też siebie nawzajem, byli dla siebie nawzajem, żyjąc we wzajemnej miłości. Stąd centralne miejsce w życiu i nauczaniu Jezusa zajmuje przykazanie miłości Boga i bliźniego. Kto raz doświadczył Boga jako miłującego Ojca, nie potrafi już nic innego jak kochać. I to właśnie jest ten „nowy człowiek”, wyzwolony przez Boga 
w Jezusie Chrystusie ze śmierci do życia, uleczony ze swojego wewnętrznego rozdarcia, niezdolności do nawiązywania bliskich i trwałych relacji. Dlatego w 1 Liście św. Jana czytamy:

My wiemy, że przeszliśmy ze śmierci do życia, bo miłujemy braci, kto zaś nie miłuje, trwa w śmierci. Każdy, kto nienawidzi swego brata, jest zabójcą, a wiecie, że żaden zabójca nie nosi w sobie życia wiecznego. (1 J 3, 14-15)

Chrystusowa „wiedza o życiu”, Jego „mądrość życiowa”, Jego „prawda o życiu” ukazuje nam zatem nowy sposób życia. Nowe jest w nim przede wszystkim podejście do zasadniczych życiowych doświadczeń, możliwości, dążeń czy pragnień człowieka, wyrażonych w wymienionej wcześniej triadzie: płeć, ambicja i pieniądz. Jezus każdemu, kto żyje „po nowemu”, kto żyje tak jak On, doradza jakościowo nowe podejście do tych trzech podstawowych wymiarów ludzkiego życia. Pożądaniu, pysze i chciwości przeciwstawia rady ewangeliczne: czystość (zob. Mt 19,12), posłuszeństwo (zob. J 5, 30; Hbr 5, 8) i ubóstwo (zob. Mt 19, 21) ${ }^{9}$, i wzywa człowieka, aby korzystając z tych podstawowych życiowych możliwości, pamiętał o drugim człowieku; wzywa go nawet do radykalnego oddania ich Bogu i wejścia tym samym na najpewniejszą drogę ku pełni życia.

Życie spełnione, prawdziwe to, według Jezusowej „wiedzy życiowej”, nie tylko życie po śmierci ${ }^{10}$. Już teraz przechodzimy do życia, gdy miłujemy się wzajemnie. Miłość Boga przemienia nas już w tym życiu, całkowicie przeorientowuje nasze „tutejsze” życie. Dlatego porównując siebie do dobrego pasterza, Jezus mówi: „Ja przyszedłem po to, aby [owce] miały życie i miały je w obfitości” (J 10, 10). Jest to

9 Zob. P. M. Zulehner, Leibhaftig glauben, dz. cyt., 49-68; por. tenże, Ungehaltene Hirtenreden. Menschlichkeit darf maßlos sein, Freiburg i. Br. 1988, s. 66-77.

10 Zob. tenże, Schronienie dla duszy. Ćwiczenia duchowe dla niezbyt pobożnych, tłum. A. Kalbarczyk, Poznań 2006, s. 14. 
życie rodzące się z bliskich, głębokich więzi, a więc z miłości do Boga i drugiego człowieka. Takie życie - mimo że często jeszcze fragmentaryczne, niekompletne - zaczyna się już tu i teraz. Znakiem i narzędziem tego życia, czyli „wewnętrznego zjednoczenia z Bogiem i jedności całego rodzaju ludzkiego" jest Kościół w Chrystusie (KK 1).

To „życie w obfitości” określane jest też jako „prawdziwe” (zob. 1 Tm 6, 19). W języku Biblii „prawdziwe” znaczy „takie, jak widzi je Bóg"11. To nam przypomina, że od samego początku (w akcie stworzenia) i dalej poprzez nieustanne zaangażowanie Boga (w głosie proroków; w dziejach objawienia), przede wszystkim zaś poprzez życie, śmierć i zmartwychwstanie Jezusa Chrystusa to życie w pełni, „w obfitości”, życie w prawdzie (zob. np. J 17, 17-19) jest dla nas darem z rąk Bożych.

\section{Tajemnica Chrystusa w centrum przepowiadania i życia człowieka}

Kościół przez swoje duszpasterstwo i posługę głoszenia słowa Bożego ma nade wszystko pomóc człowiekowi żyć teraz i w wieczności, dając mu w Chrystusie życiową orientację i sens życia. Cel ten osiąga, gdy dzięki niemu człowiek potrafi w wierze, nadziei i miłości powierzyć się całkowicie żywemu i prawdziwemu Bogu, któremu zależy na tym, by człowiek żył i który jako źródło i cel człowieka stanowi jego środek.

Dlatego kościelne przepowiadanie powinno prowadzić ludzi do wiary w żywego i prawdziwego Boga, umieszczając w swoim centrum Osobę Jezusa Chrystusa. On jest tym, w którym Bóg jako Ojciec życia spotyka się z ludźmi i pociąga ich ku sobie (por. CTr 5). Przez zjednoczenie z Jezusem Chrystusem ludzie jednoczą się z Bogiem 
jako swoim Ojcem i zarazem ze sobą nawzajem ${ }^{12}$. Takie chrystocentryczne przepowiadanie nie polega więc jedynie na przekazywaniu zbioru suchych twierdzeń na temat Boga, świata i człowieka, lecz na głoszeniu ludziom świadectwa, którym jest ludzkie życie Jezusa Chrystusa i w którym zawiera się orientacja i interpretacja, tajemnica ich życia. W słowach, czynach, śmierci i zmartwychwstaniu Jezusa Chrystusa Bóg objawia się jako ten, który swoją zbawczą mocą pragnie przywrócić pełnię życia człowiekowi i całemu stworzeniu ${ }^{13}$. Dlatego każdy, kto przyjąwszy tę prawdę, pragnie przekazać ją innym, musi dać świadectwo swojej żywej więzi z Jezusem Chrystusem jako Nauczycielem życia.

Chrześcijanie stale na nowo uczą się spoglądać na świat, na swoje radości i smutki, nadzieje i lęki, tęsknoty i cierpienia przez pryzmat tajemnicy Jezusa Chrystusa, Jego wiedzy o życiu, dostrzegając w niej Boga czyniącego wszystko, by obdarzyć człowieka życiem w pełni. Życie chrześcijan polega więc na nieustannym odpowiadaniu na wezwanie do wejścia - tak w pojedynkę, jak i we wspólnocie - na drogę, którą przeszedł Jezus Chrystus, którą On stale na nowo i coraz to szerzej im wytycza i na której - zgodnie ze swoją obietnicą - będzie im zawsze towarzyszył aż do skończenia świata.

To, że prawdą chrześcijan jest życie Jezusa Chrystusa, decyduje o ich stosunku do wiary i określa kształt kościelnego przepowiadania. Jezus Chrystus głosił prawdę i żył prawdą. On sam jest prawdą poprzez swoje cierpienie i śmierć, dające życie światu. Prawda, którą jest Osoba Jezusa Chrystusa i do której ma prowadzić posługa słowa w Kościele, jest prawdą wymagającą głoszenia, słuchania i rozważania, ale też i praktykowania w życiu. Ukierunkowanie przepowiadania na Osobę Jezusa Chrystusa, nadanie mu chrystocentrycznego

12 Zob. D. Emeis, Katechese, w: G. Bitter, G. Miller, Handbuch religionspädagogischer Grundbegriffe, t. I, München 1986, s. 169-171.

13 Zob. P. M. Zulehner, Wie Musik zur Trauer ist eine Rede zur falschen Zeit. Wider den kirchlichen Wort-Durchfall, Ostfildern 1998, s. 63. 
charakteru, usuwa antagonizm między prawdziwą nauką (ortodoksją) a prawdziwym życiem (ortopraksją) ${ }^{14}$. Stąd życie Jezusa może być głoszone wyłącznie jako prawdziwe życie, gdyż takim się okazało w Jego nauczaniu o Bogu - tajemnicy życia człowieka. Prawdę, którą głosił Jezus i którą jest On sam, odnajdzie tylko ten, kto próbuje nią żyć. Dlatego też tajemnicy Chrystusa nie da się nigdy zgłębić jedynie teoretycznie; trzeba ją też praktycznie „przeżyć, a to znaczy również: w życiu i śmierci „przecierpieć”. To zaś stawia przepowiadanie kościelne przed koniecznością ciągłego pytania o to, jak tajemnica Chrystusa, jak Jego „wiedza o życiu” może być dzisiaj praktykowana, jak ukazywać prawdę o ludzkim życiu i jakimi drogami do niej dochodzić.

Głoszenie słowa Bożego ma prowadzić do poznania tajemnicy Jezusa Chrystusa i zawartej w niej tajemnicy człowieka oraz jego życia w świecie ${ }^{15}$. „Tajemnica” nie oznacza zakrytej prawdy, która po jej odkryciu przestaje być tajemnicą. Przeciwnie: im głębiej wierzący wnika w prawdę Jezusa Chrystusa, w Jego „mądrość życiową”, rozważając ją i żyjąc nią, tym dobitniej jawi mu się ona jako tajemnica, tym bardziej zdumiony przygląda się swojemu życiu, wplecionemu w świat i jego dzieje, właśnie jako tajemnicy. Właściwy człowiekowi od czasów nowożytnych sposób badania, nauczania i uczenia się każe mu wszystko w tym świecie rozkładać na czynniki pierwsze i tłumaczyć za pomocą związków przyczynowo-skutkowych, w przekonaniu, że to właśnie czyni jego życie coraz bardziej przewidywalnym, możliwym do zaplanowania i sensownym. Dużo rzadsze są takie formy poznawania, nauczania i uczenia się, w których człowiek pyta o sens całości, bada tęsknoty swojego serca i szuka źródła swojej nadziei. Taki sposób patrzenia na rzeczywistość jest zgłębianiem tajemnicy życia. Jednakże prawda, do której się poprzez nie dochodzi,

14 Zob. D. Emeis, Katechese, dz. cyt., s. 170.

15 Zob. A. Kalbarczyk, Jak mówić w kazaniach o życiu doczesnym i wiecznym?, „Biblioteka Kaznodziejska" 6 (2008) nr 152, s. 29-33. 
nie jest prawdą, która daje się w każdej chwili szczegółowo wyłożyć i którą każdy może poznać i sobie przyswoić. Prawda tajemnicy otworzy się tylko przed tym, kto otworzy się na nią, pozwoli jej do siebie przemówić, wykorzysta sprzyjający temu czas i zda się na nią całkowicie w życiu i śmierci. Stąd też przepowiadanie nie zawsze i nie w każdym osiąga swój cel. Człowiek bowiem musi chcieć znaleźć miejsce, czas, a przede wszystkim ludzi, umożliwiających mu spotkanie z tajemnicą Jezusa Chrystusa, otwierającą mu dostęp do Jego „życiowej mądrości”.

Jeśli celem kościelnego przepowiadania jest znajomość wiary nie tylko w sensie wiedzy przedmiotowej, czyli obeznania w wierze jako doktrynie, lecz przede wszystkim wiedzy o życiu, czyli obeznania w możliwościach życia, jakie daje wiara, to wiąże się to z poważnymi konsekwencjami dla metod i środków głoszenia słowa Bożego. Cenną propozycją w tym zakresie jest koncepcja homilii jako interpretacji ludzkiego życia w świetle tekstów świętych, uzdalniającej wspólnotę do rozpoznania obecności i działania Boga oraz do odpowiedzi na tę obecność poprzez wiarę i życie zgodne z Ewangelią, zaproponowana przez katolickich homiletów amerykańskich w dokumencie Komisji Episkopatu Stanów Zjednoczonych ds. Życia i Posługi Kapłanów: Fulfilled in your hearing. The homily in the Sunday assembly z 1982 roku $^{16}$. Koncepcja ta opiera się m.in. na dialogicznej teologii Objawienia, na przekonaniu, iż jest ono „ulokowane w historii ludzkiej, w głębi ludzkiego doświadczenia” oraz na współczesnej chrystologii oddolnej, która wychodzi od człowieczeństwa Jezusa i stopniowo dochodzi do tajemnicy Jego boskości ${ }^{17}$.

16 Zob. Homilia niedzielna. Dokumenty Konferencji Episkopatu Stanów Zjednoczonych, tłum., opr. i red. H. Sławiński, Kraków 2015, s. 89-135.

17 Zob. H. Sławiński, Między ciaggłościq a zmianq. Teoria homilii w Stanach Zjednoczonych po Il Soborze Watykańskim, Kraków 2008, s. 104-145; tenże, Homilie: ihre gegenwärtigen Herausforderungen im Spiegel historischer Entwicklung, w: Mit Sprache bewegen. Festschrift für Prof. Dr. Michael Thiele zu seinem 65. Geburtstag, Hrsg. von S. Göpferich, E. Kucharska-Dreiß, P. Meyer, Insingen 2012, s. 257-269. 
Jakąkolwiek wiedzę najlepiej przekazuje się w grupie ludzi. Dlatego Jezusową wiedzę o życiu najłatwiej jest przekazywać, przejmować i rozwijać poprzez udział w życiu wspólnoty wiary. To zaś oznacza, że w przepowiadaniu pierwszeństwo mają te metody, które umożliwiają rzeczywiste życie według wiary. Należy zatem preferować metody, które ukierunkowane są na dialog, komunikację i partycypację. Tam, gdzie w nauczaniu kościelnym nie idzie wyłącznie o wiedzę na temat wiary, lecz przede wszystkim o życie z wiary, tam potrzebni są świadkowie wiary, z którymi i za których przykładem wejść można we wspólnotę wiary i życia. Takie uczenie się życia z wiary od innych i z innymi dotyczy jednak obu stron: świadków wiary i uczniów wiary. Dlatego też przepowiadanie jest wspólną drogą, procesem, w którym wspólnota nie tylko daje, ale i otrzymuje.

Podsumowaniem niniejszych rozważań i jednocześnie czymś w rodzaju końcowej dyrektywy dla kaznodziejów, homilistów, katechetów i chrześcijańskich pedagogów interpretujących ludzkie życie w świetle tajemnicy Chrystusa niech będą słowa św. Jana Pawła II $\mathrm{z}$ jego homilii wygłoszonej w dniu inauguracji jego pontyfikatu:

Nie obawiajcie się przyjąć Chrystusa! [...] Nie lękajcie się! Otwórzcie, otwórzcie na oścież drzwi Chrystusowi! [...] Nie lękajcie się! Chrystus wie, „co jest w człowieku”. Tylko On to wie! Dzisiaj tak często człowiek nie wie, co nosi w sobie, w głębi swojej duszy, swego serca. Tak często jest niepewny sensu swego życia na tej ziemi. Tak często opanowuje go zwątpienie, które przechodzi w rozpacz. Pozwólcie zatem - proszę was, błagam was z pokorą i ufnością pozwólcie Chrystusowi mówić do człowieka. Tylko On ma słowa życia, tak, życia wiecznego. ${ }^{18}$

18 Jan Paweł II, Nie lękajcie się! Otwórzcie drzwi Chrystusowi! Homilia wygłoszona w dniu inauguracji pontyfikatu, 22.10.1978: AAS 70 [1978], s. 945-947. 
Jeżeli człowiek ma otworzyć „na oścież drzwi Chrystusowi”, aby stanął On w centrum jego życia, to Chrystus i Jego tajemnica muszą stanowić też centrum, serce kościelnego przepowiadania oraz określać jego formy i metody. Nie może ono jednak polegać wyłącznie na przekazie wiedzy o Chrystusie i Jego życiu, lecz ma prowadzić do żywego spotkania z Nim - Nauczycielem życia i jednocześnie Towarzyszem na drogach życia, który jako jedyny wie, „co jest w człowieku”. Współczesny człowiek, mimo że gubi się nieraz w potoku różnorakich informacji, prawd i mądrości, płynącym ku niemu każdego dnia, nie przestaje poszukiwać sensu, orientacji i trwałego oparcia w życiu. Dlatego potrzebuje on takiego przepowiadania, które mu przede wszystkim unaoczni, że wiara jest czymś, co pomaga żyć. W związku z tym powinno ono też dopuścić i uwzględnić pytanie, jakie ludzie dziś często zadają: „Co daje mi wiara w Jezusa Chrystusa?”. Nie jest to pytanie o użyteczność wiary, o jakieś bezpośrednie, wymierne korzyści z niej płynące, lecz o znaczenie wiary w życiu osobistym. $Z$ tego względu przepowiadanie należy dziś zdecydowanie przenieść z płaszczyzny nauczania na płaszczyznę relacji, świadectwa, a przez to także na płaszczyznę dialogu. Doskonale wyrażają to słowa św. Pawła: „Kochając was tak bardzo, pragnęliśmy dać wam nie tylko ewangelię Bożą, lecz i nasze życie, ponieważ staliście się nam drodzy" (1 Tes 2, 8). Tylko w ten sposób Kościół może zafascynować człowieka życiem, jakie daje Jezus Chrystus, i stylem życia, jaki proponuje Jego Ewangelia.

\section{Chrystocentryczna interpretacja ludzkiego życia w przepowiadaniu}

\section{Streszczenie}

Kościół od wieków głosi niezmiennie, że pewną, niezawodną drogą ku pełni życia jest Jezus Chrystus. Dlatego ludziom wszystkich czasów przekazuje Jego tajemnicę, mądrość życiową, wiedzę o życiu. W centrum Jego drogi życiowej jest Bóg żywy, Dawca życia, kochający Ojciec, który wychodzi człowiekowi naprzeciw 
i pragnie, aby człowiek odkrył w Nim źródło swojego życiowego spełnienia. Jezusowa wiedza o życiu ukazuje całkowicie nowy sposób życia, nowe podejście do zasadniczych doświadczeń i dążeń ludzkich. W ten sposób Jego interpretacja życia nie tylko daje człowiekowi tak bardzo potrzebną mu orientację życiową, lecz także jego życie gruntownie przeorientowuje.

Jeżeli tajemnica Chrystusa ma stać w centrum życia człowieka, to musi ona stanowić też centrum, serce kościelnego przepowiadania i decydować o jego formach i metodach. Nie może się ono ograniczać do przekazu wiedzy o Chrystusie i Jego życiu, lecz ma prowadzić do żywego spotkania z Nim - Nauczycielem życia, Tym który jako jedyny wie, „co jest w człowieku”.

Słowa kluczowe

chrystocentryzm, przepowiadanie, ludzkie życie, interpretacja

\section{Christocentric interpretation of human life in preaching}

Summary

For centuries the Church has constantly proclaimed that only Jesus Christ is the secure and reliable path to the fullness of life. Therefore, people of all times are conveyed His mystery, life wisdom and knowledge. In the heart of His way stands the living God, the Giver of life, a loving Father who meets everybody halfway and desires all to discover in Him the source of fulfilment. Jesus ` knowledge of life demonstrates the completely new way of it, the new approach to basic and fundamental human experiences and aspirations. Thus His interpretation presents to everyone not only much-needed orientation in life, but it also thoroughly reorients it.

If the mystery of Christ, His truth, is to become the centre of human life, it must also be the heart of the Church `s preaching and determine its forms and methods. It cannot be limited to the transmission of knowledge about Christ and His life, but should lead to a vivacious encounter with Him - the Teacher of life, the one who alone knows "what is in man".

Keywords

christcentrism, preaching, human life, interpretation 


\section{Bibliografia}

Emeis D., Katechese, w: G. Bitter, G. Miller, Handbuch religionspädagogischer Grundbegriffe, t. I, München 1986, s. 167-173.

Homilia niedzielna. Dokumenty Konferencji Episkopatu Stanów Zjednoczonych, tłum., opr. i red. H. Sławiński, Kraków 2015.

Kalbarczyk A., Jak mówić w kazaniach o życiu doczesnym i wiecznym?, „Biblioteka Kaznodziejska" 6 (2008) nr 152, s. 29-33.

Sławiński H., Między ciq̨głościq a zmianq. Teoria homilii w Stanach Zjednoczonych po Il Soborze Watykańskim, Kraków 2008.

Sławiński H., Homilie: ihre gegenwärtigen Herausforderungen im Spiegel historischer Entwicklung, w: Mit Sprache bewegen. Festschrift für Prof. Dr. Michael Thiele zu seinem 65. Geburtstag, Hrsg. von S. Göpferich, E. Kucharska-Dreiß, P. Meyer, Insingen 2012, s. 257-269.

Zulehner P. M., Helft den Menschen leben. Für ein neues Klima in der Pastoral, Freiburg i. Br. 1978.

Zulehner P. M., Leibhaftig glauben. Lebenskultur nach dem Evangelium, Freiburg i. Br. 1983.

Zulehner P. M., Wie Musik zur Trauer ist eine Rede zur falschen Zeit. Wider den kirchlichen Wort-Durchfall, Ostfildern 1998. 